\title{
THE USE OF MICRONUTRIENTS TO CONTROL CHOCOLATE LEAF SPOT AND RUST OF FABA BEAN AND TO ENHANCE ITS GROWTH CHARACTERISTICS AND YIELD UNDER FIELD CONDITION \\ Morsy, S. M. A. and S. A. El. Morsy \\ Plant Pathology Res. Inst., Agric. Res. Center, Giza, Egypt.
}

\begin{abstract}
Under field conditions, in the two successive seasons of 2010/11 and 2011/12 the effect of plant spraying with commercial chelated iron, manganese and zinc on severity of chocolate leaf spot and rust of faba bean cv. Misr 1 was studied. The effects on leaves chlorophyll content and some agronomic characters of the faba bean were also investigated.

Severity of Botrytis fabae was significantly decreased on the treated plants and reduced the disease incidence between $7.93 \%$ to $36.9 \%$ compared with control .Also, microelements decreased rust disease severity between $15.4 \%$ to $62.8 \%$ in the two growing seasons, respectively .

Chlorophyll (a) and (b) in leaves significant increased in all plants sprayed with micronutrients. Also, results showed that spraying faba bean plants with $\mathrm{Fe}, \mathrm{Zn}$ and $\mathrm{Mn}$ alone or in combination increased plant height, number of pods / plant, 100 seed weight and seed yield / feddan .
\end{abstract}

\section{INTRODUCTION}

Faba bean is an important legume crop in Egypt due to its high nutritive value in both energy and protein contents and it is a primary source of protein in the diet of masses. Therefore, increasing the crop production is one of the most important targets of agricultural policy in Egypt. However, this strategic crop is suffering from many destructive diseases. It is attacked by more than 100 pathogens in the Mediterranean region (Hebblethwaite, 1983).

Chocolate leaf spot caused by Botrytis fabae is an important disease worldwide occurring almost in all regions where faba bean is growing (Rahman et al., 2002).

The disease appears as lesions on leaves, flowers and stems with reddish to chocolate brown color, with darker margins that are fairly defined and often of a concentric circular pattern. (Harrison, 1988). The spots led to harmful effects on growth, physiological activities and yield (Khaled et al., 1995).

Also rust disease caused by Uromyces fabae Pers. Schroet. is an important limiting factor which causes great annual losses and sometimes complete crop failure (Mohamed, 1982, and Hanounik and Bisri, 1991).

The infection by Uromyces fabae firstly by appears as minute, slightly raised, white to cream colored spots on leaves and to a lesser extent on stems. As spots enlarge the epidermis rupture, releasing masses of dark brown spores (urediospores) to form characteristic pustules (Uredia). The pustules are often surrounded by a ring of yellow tissue. On highly 
susceptible cultivars, rust build up rapidly until most of the leaves are covered with pustules. Severely infected leaves rapidly dry up and premature defoliation may occur (Benier et al., 1993)

Biological control of $B$. fabae by different bio-agents is reported by Cook and Baker (1983). Abd-El-Moiety and Abu-Zied (1985) and Omar et al. (1987). Essential oil extracts have been considered as natural preservatives or food additives and can be used for controlling pathogens (Naidu, 2000), because of their biocidal effects on bacteria, fungi, viruses, protozoa, insects and plants (Kalemba and Kunicka, 2003).

Many chemicals traditionally used to control chocolate spot and rust disease are becoming less effective (Harrison, 1988), giving only partial disease control despite of the high cost of their use and adverse environmental effects on the accompanying microflora (Khaled et al., 1995). So, faba bean is in a growing need to develop alternative approaches for controlling plant disease. Induced resistance due to foliar application with microelements in some plants against plant disease was reported by (Abd-ElKarem et al. 2004, and El-Gamal et al., 2007). Microelements were applied successfully in many areas of plant production as a plant growth stimulant (Scheuerll and Mahafee, 2006).

Chlorophyll content was taken as an index for the extent of reduction in effective green area, as, the disease reduces the photosynthetic activity in leaves and ultimately lead to lower yields (Sinha et al. 1970). Rahhal (1993) found that microelements $\mathrm{Fe}$ and $\mathrm{Zn}$ increased concentrations of chlorophyll (a) or (b) and total content of leaves. Also, Abd El-Razek et al., (2012) recorded that micronutrients application at rate of $4 \mathrm{~g} / \mathrm{L}$ increased significantly chlorophyll a compared with control. The same trend was found in chlorophyll b content, but values were significantly lower than that of chlorophyll a.

Spraying faba bean by micronutrients under field conditions in Egypt was found to increase the plant height compared with control. This was in agreement with Bozorgi et al., (2011). Also, number of pods / plant, 100 seed weight and seed yield/ fadden were increased by spraying micronutrients compared with non treated plants El-fouly et al., (2010).

The present study therefore, was amid to study the influence of micronutrients on the alleviation of damage of chocolate spot and rust diseases on faba bean, chlorophyll $a$ and $b$ content and certain growth characteristics, yield and its components.

\section{MATERIALS AND METHODS}

\section{Field Experiments :}

The experiments were carried out at Etay El- Baroud Agric. Res. St. in the two successive seasons of 2010/2011 and 2011/12. Faba bean seeds (Vicia faba) cv. Misr 1 were sown on $1^{\text {st }}$ November, in $3 \mathrm{~m}$ - long rows and each four rows represented one replicate. Each treatment was replicated three times in a randomized complete block design. The experiment includes nine treatments which were as the following :

- Spraying plants with water only (control) 
- Spraying plants with (Fe 12.5\%)

- Spraying plants with (Zn 12.5\%)

- Spraying plants with (Mn 12.5\%)

- Spraying plants with $(\mathrm{Fe}+\mathrm{Mn})$

- Spraying plants with $(F e+Z n)$

- Spraying plants with $(Z n+M n)$

- Spraying plants with $(\mathrm{Fe}+\mathrm{Zn}+\mathrm{Mn})$

- Spraying plants with (Diathane M - 45 )

Treatments were applied three times, the first one at 45 days after sowing, followed by the other two sprays at 10 days intervals. Commerical chelated $\mathrm{Fe}, \mathrm{Mn}$ and $\mathrm{Zn}$ were used in the experiment at rate of $4 \mathrm{~g} / \mathrm{L}$. water while, Diathane M- 45 was used at the at rate of $250 \mathrm{~g} / 100 \mathrm{~L}$. water.

Disease assessment : The disease severity of chocolate leaf spot disease was recorded at the $75^{\text {th }}$ day from sowing using the scale of Bernier et al . (1993), as follows :

$1=$ no disease symptoms or very small specks ( Highly resistante )

3 = few small discrete lesions ( Resistante ).

$5=$ some coalesced lesions with some defoliation ( Moderately resastante ).

7 = Large coalesced sporulating lesion, 50\% defoliation, some dead plants (Susceptible ).

9 = extensive lesions on leaves, stems, and pods ;severe defoliation; heavy sporulation; stem girdling; blackieng and death of more than $80 \%$ of plant ( Highly susceptible ). The formula adopted by Hanounik (1986) was used to estimate the percentage of chocolate spot severity :

Disease severity (D.S.) \% $=\frac{\text { E DPCXCR }}{\text { NIPXISE }} \times 100$

$\mathrm{NPC}=$ No. of plants in each class rate

$\mathrm{CR}=$ Class rate .

NIP $=$ No. of infected plants .

MSC $=$ Maximum severity class rate .

Rust disease severity was recorded at 110 days from sowing according to the standard scale suggested by Bernier et al., (1993) as follows:

$1=$ No pustules or very small to non - sporulating flecks ( Highly resistant) . $3=$ Few scattered pustules covering less than $1 \%$ of leaf area, and few for no pustules on stem ( Resistant )

$5=$ Pustules common on leaves covering $1-4 \%$ of leaf area, little defoliation, and some pustules on stem (Moderatly resistant ).

7 = Pustules very commone on leaves, covering $4-8 \%$ of leaf area; some defoliation; and many pustules on stem ( Susceptible ).

$9=$ Extensive pustules on leaves, petioles, and stems covering $8-10 \%$ leaf area; many dead leaves and severe defoliation ( Highly susceptible ). 

analyzed.

Average of chocolate spot and rust were recorded and statistically Leaf chlorophyll determination :

Leaf chlorophyll content was determined spectrophotometically at 645 and $663 \mathrm{~nm}$ according to Grodzinsky and Grodzinsky ( 1973). Chlorophyll (a) and (b) concentrations in $\mathrm{mg} / \mathrm{g}$ leaves were calculated as follows :

Chl. $\mathrm{a}=(12.7$ EX $663-2.69$ EX 645$) \times 0.1$

$\mathrm{Chl} . \mathrm{b}=(22.9 \mathrm{EX} 645-4.68 \mathrm{EX} 663) \times 0.1$

Agronomic traits :

At harvest time( 120 days after sowing ) ten guarded plants were taken from each plot to estimate the following characters .

1- Plant height (CM)

2- Number of branches / plant .

3- Number of pods / plant .

4- 100 - seed weight $(\mathrm{g})$.

5- Seed yield / feddan (ton).

plants in each plot were hervasted and left for air drying, then they were threshed and the seeds (which were at $12 \%$ moisture ) were weighted $(\mathrm{Kg})$.

\section{Statistical analysis}

All data were statistically analyzed in two seasons using "MSTAT-C" statistical package. Least Significant Difference (LSD) method was used to test the differences between treatment means at $5 \%$ of probability.

\section{RESULTS AND DISCUSSION}

\section{Field experiments :}

Effect of some chelated micronutrients on severity of chocolate leaf spot disease on faba bean plants.

Data presented in Table ( 1 ) showed that spraying faba bean cv. Misr 1 with microelements three times, on 10 days intervals significantly reduced chocolate spot severity. The highest reductions i.e. $36.9 \%$ and $25.6 \%$ were recorded when $\mathrm{Zn}$ was applied at the to growing seasons, respectively. This was followed by Mn which reduces disease severity by $34.8 \%$ and $28.3 \%$ at the two successive seasons 2010 and 2011, respectively. The disease reduction obtained of however, with the use of $\mathrm{Mn}$ was not significantly different of that obtained by the use of the fungicide Diathane M 45.

These results are in agreement with the findings of Rahhal (1993) who found that chocolate spot severity was generally low when Mn was applied as $(8 \mathrm{gm} / \mathrm{L})$ and $\mathrm{Zn}$ was applied as $8 \mathrm{gm} / \mathrm{L}$. Also, Abd El - Hai et al. (2009) found that the application of manganese combined with zinc was more effective than the microelements alone against Rhizoctonia solani and Macrophmmina phaseolina in sunflower plants .Generally, disease severity decreased through the three heights of the plant assessment treatments.

Table (2) Micronutrients decreased severity of rust disease between $15.4 \%$ to $62.8 \%$ in the two successive growing seasons 2010/2011 and $2011 / 2012$. 
J. Plant Prot. and Path., Mansoura Univ., Vol. 4 (4), April, 2013

$1-2$ 
Also, the high part of plants at $60 \mathrm{~cm}$ upper of the land surface was highest affected with disease than at $40 \mathrm{~cm}$ or $20 \mathrm{~cm}$. It is clear that in the first season $\mathrm{Fe}+\mathrm{Zn}+\mathrm{Mn}$ as a combination had the best effect, it decreased rust disease to $6.03 \%$ compared with un-treated control $(16.4 \%)$ which resulted in disease reduction of $62.8 \%$ followed by $\mathrm{Zn}(7.47 \%)$ alone and $\mathrm{Fe}+\mathrm{Mn}$ ( $8.6 \%$ ), respectively .However, in the second season 2011/ 2012 the best effect was obtained when $\mathrm{Zn}$ applied alone followed by $\mathrm{Mn}$ alone and $\mathrm{Fe}+\mathrm{Zn}+\mathrm{Mn}$ where rust severities were $5.1 \%, 7.6 \%$ and $7.9 \%$, respectively .

Diseases decreased when micronutrients used as spray against some diseases of faba bean plants due to stimulating biological activities, i.e. , enzyme activity, chlorophyll synthesis, rate of translocation of photosynthetic products and nutrient. (Foilett et al ., 1981) .

Effect of spraying by faba bean with micronutrients on the chlorophyll content of leaves :

The effect of micronutrients on the chlorophyll content of leaves was presented in Table (3). The highest concentrations of chlorophyll (a) content of leaves which were $0.86 \mathrm{mg} / \mathrm{g}$ leaves and $0.83 \mathrm{mg} / \mathrm{g}$ leaves were obtained with foliar applications of $\mathrm{Mn}$ alone or( $\mathrm{Fe}+\mathrm{Mn})$ or $(\mathrm{Zn}+\mathrm{Mn})$, respectively.Meantime, the highest concentrations of chlorophyll (b) i.e. $0.56,0.51$ and $0.51 \mathrm{mg} / \mathrm{gm}$ leaves were obtained when faba bean plants were sprayed with $\mathrm{Mn}$ or $\mathrm{Zn}$ alone and $(\mathrm{Fe}+\mathrm{Mn}$ ), respectively . The total chlorophyll content of leaves showed the highest concentrations in case of $\mathrm{Mn}$ alone and ( $\mathrm{Fe}+\mathrm{Mn})$ treatments which were 1.42 and $1.34 \mathrm{mg} / \mathrm{g}$ leaves, respectively. Al Juburi et al. (1992) reported that sprayed mandarin tress with $\mathrm{Fe}, \mathrm{Mn}, \mathrm{Zn}$ and $\mathrm{Cu}$ separately or as a smixture as sulphate increased chlorophyll content alternatively without regular pattern during the two growing seasons.

Table (3) : Effect of some chelaled micromutrients as spray treatments on the chlorophyll $a, b$ and the total chlorophyll content (mg / g leaves).

\begin{tabular}{|l|c|c|c|}
\hline \multicolumn{1}{|c|}{ Elements } & $\begin{array}{c}\text { Chlorophyll } \\
\text { (a) }\end{array}$ & $\begin{array}{c}\text { Chlorophyll } \\
\text { (b) }\end{array}$ & $\begin{array}{c}\text { Total chlorophyll } \\
(\mathbf{a + b})\end{array}$ \\
\hline $\mathrm{Fe}$ & 0.77 & 0.45 & 1.22 \\
$\mathrm{Zn}$ & 0.81 & 0.51 & 1.32 \\
$\mathrm{Mn}$ & 0.86 & 0.56 & 1.42 \\
$\mathrm{Fe}+\mathrm{Zn}$ & 0.80 & 0.48 & 1.26 \\
$\mathrm{Fe}+\mathrm{Mn}$ & 0.83 & 0.51 & 1.34 \\
$\mathrm{Zn}+\mathrm{Mn}$ & 0.83 & 0.49 & 1.32 \\
$\mathrm{Fe}+\mathrm{Zn}+\mathrm{Mn}$ & 0.80 & 0.46 & 1.26 \\
Diathean M. 45 & 0.72 & 0.42 & 1.14 \\
Check (un - treated) & 0.62 & 0.40 & 1.02 \\
\hline L.S.D at 0.05\% & 0.134 & 0.155 & \\
\hline
\end{tabular}

Values are averages of two seasons. 


\section{Correlation between disease severity on faba bean and chlorophyll (a and $b$ ).}

A considerable positive correlation ( $r=0.996$ and -1$)$ was revealed between disease severity \% of chocolate leaf spot and content of chlorophyll (a) in faba bean plant Fig.(1) while, less correlation coefficient of $(r=-0.008$ and - 0.023 ) was recorded for the D.S.\% and chlorophyll (b) in the two growing seasons 2010 and 2011 respectively, Fig.(2).

Also,the disease severity \% of rust and content chlorophyll (a)in faba bean plant was highly correlation ( - 0.876 and 0.933 )whil, less correlation coefficient between rust diseases severity \% and chlorophyll (b) in two growing seasons 2010 and 2011, respectively.

\section{Effect of micronutrients on growth characteristics of faba bean :}

Data presented in Table (4) showed that, the foliar applications with $\mathrm{Fe}, \mathrm{Zn}$ and $\mathrm{Mn}$ alone or in combination of them enhanced significantly all growth characteristics. Plant height was highly significant affected by foliar application in the combined date ( Table 4 ). The highest plant height ( 99.7 $\mathrm{cm}$ ) was obtained with spraying $\mathrm{Fe}+\mathrm{Zn}$ followed by $\mathrm{Fe}+\mathrm{Zn}+\mathrm{Mn}$ ( 95.58 $\mathrm{cm})$ and $\mathrm{Mn}+\mathrm{Zn}(94.62 \mathrm{~cm})$, while the lowest heig $(83.88 \mathrm{~cm})$ was recorded with un-treated (control). These result are agreement by Bozorgi et al. (2011).

The highest number of branches / plant was obtained with spraying faba bean plants with $\mathrm{Fe}+\mathrm{Zn}+\mathrm{Mn}$ ( 3.2 branches / plant ) followed by $\mathrm{Fe}+$ $\mathrm{Zn}$ ( 3.0 branches plant ) while, the lowest values of number of branches / plant was found in the un - treated plants ( control).

The highest number of pods / plant (12.4) was obtained with of $\mathrm{Fe}+$ $\mathrm{Zn}$ followed by ( 10.4 pods / plant ) when spraing with $\mathrm{Fe}+\mathrm{Zn}$. However, spraying with $\mathrm{Fe}$ or $\mathrm{Zn}$ alone resulted in 9.6 and 8.2 pods / plant, respectively.

These results were the harmony with El - Fouly et al . (2010) and Bozorgi et al. (2011). On the other hand Amin et al ., (1988) and El- Masri et al . (2002) found that, two sprays of zinc resulted in the highest number of pods per plant.

Data in Table (4) showed that spraying $\mathrm{Fe}+\mathrm{Zn}$ recorded the highly significant value $(94.06 \mathrm{gm})$ of 100 seed weight compared with the other treatments and control, Yassen et al., (2010) found that, the highest increment (16\%) was obtained when plants were sprayed with micronutrients mixture $(\mathrm{Fe}+\mathrm{Zn}+\mathrm{Mn})$ as compared with control treatment .

Spraying with $\mathrm{Fe}+\mathrm{Zn}$ exhibited the highest value ( 3.8 ton / fed. ) of seeds yield / fad in the combined data as shown in Table (4), followed by $\mathrm{Fe}$ $+\mathrm{Zn}+\mathrm{Mn}$ ( 3.7 ton / fed .) and Fe $+\mathrm{Mn}$ ( 3.6 ton / fed .) compared with control for the two growing season of 2010 and 2011. Allam et al. (2004) reported that, the foliar spray with the combination of $(\mathrm{Fe}+\mathrm{Mn}+\mathrm{Zn})$ showed a highly significant increase in broad bean seed yield.

Abd El- Hai et al., (2009) found that microelements were on enhancing the stem and flower head diameters . 
Morsy, S. M. A. and S. A. El. Morsy

Fig.(1).Correlation between disease severity \%of chocolate leaf spot and chlorophyll a) content in faba bean plant two growing seasons.

Fig.(2).Correlation between disease severity \% of chocolate leaf spot and chlorophyll(b) content in faba bean plant two growing seasons. 
J. Plant Prot. and Path., Mansoura Univ., Vol. 4 (4), April, 2013

Fig.(3).Correlation between disease severity \%of rust and chlorophyll(a) content in faba bean plant two growing seasons.

Fig.(4).Correlation between disease severity \%of rust and chlorophyll(b) content in faba bean plant two growing seasons. 
El.Sayed et al. (2011) found that the foliar spraying of pea plants with a mixture of microelements significantly increased yield components expressed as pod length pod weight, number of green seeds ( pod. weight of 100 - green seed, seed index, 1000- dry seed weight and chemical constituents.

Table (4) : Effect of foliar application with some micronutrients on growth, yield and yield components of faba bean plants.

\begin{tabular}{|l|c|c|c|c|c|}
\hline \multicolumn{1}{|c|}{ Treatments } & $\begin{array}{c}\text { Plant height } \\
\text { (cm) }\end{array}$ & $\begin{array}{c}\text { l. of branches } \\
\text { / plant }\end{array}$ & $\begin{array}{c}\text { of pods / } \\
\text { plant }\end{array}$ & $\begin{array}{c}\text { 100 seed } \\
\text { weight (g) }\end{array}$ & $\begin{array}{c}\text { Seed yield / } \\
\text { faddan } \\
\text { (ton ) }\end{array}$ \\
\hline $\mathrm{e}$ & 88.22 & 2.8 & 9.6 & 89.32 & 2.93 \\
$\mathrm{e}+\mathrm{Zn}$ & 99.7 & 3.0 & 12.4 & 94.06 & 3.8 \\
$\mathrm{e}+\mathrm{Mn}$ & 92.64 & 2.6 & 10.4 & 89.78 & 3.6 \\
$\mathrm{e}+\mathrm{Zn}+\mathrm{Mn}$ & 95.58 & 3.2 & 10.2 & 90.0 & 3.7 \\
$\mathrm{n}$ & 91.02 & 2.6 & 8.2 & 87.12 & 3.2 \\
hn $+\mathrm{Zn}$ & 94.62 & 2.6 & 10.0 & 90.12 & 3.0 \\
hn & 89.42 & 2.6 & 10.0 & 88.0 & 3.1 \\
iathean M 45 & 91.14 & 2.8 & 10.0 & 90.12 & 2.9 \\
ontrol & 83.88 & 2.4 & 7.6 & 86.04 & 2.5 \\
\hline S.D at 0.05 & 11.64 & $\mathrm{Ns}$ & 3.5 & 1.4 & 1.1 \\
\hline
\end{tabular}

\section{REFERENCES}

1- Abd El-Hai, K.A., El-Metwally, S.M, El-Baz M. S. and zeid, A. M.(2009). The use of Antioxidants and microelements for controlling damping - off caused by Rhizoctonla solani and charcoal rot caused by Macrphomina phasolin on sunflower, Plant Pathal.J., 2009.

2- Abd-El-Karem, F., Nehal El-Mougy, S., El-Gamal Nadia, G. and Fatouh,Y.O. (2004). Induction of resistance in squash plants against powdery mildew and Alternaria leaf spot disases using chemical inducers as protective or therapeutic treatments. Egypt. J. Phytopathol., 32 1-2 : 65-76.

3- Abd-El-Moiety, T.H. and N.M. Abou-Zeid, (1985). Studies on the control of Botrytis fabae on faba bean in Egypt. Proceeding of the $1^{\text {st }}$ National Confference of Pests and Disease of Vegetable and Field Crops in Egypt, Ismailia, pp:779-790

4- Abd El-Razek, U.A. ; Dorgham Elham, A. and Morsy S.M. (2012). Effect of certain micronutrients on some agronomic characters, chemical constituents and Alternaria leaf spot disease of faba bean. J. Plant Production, Mansoura Univ. 3 (11): 2699-2710.

5- Allam, S.M.M., HG. Abu El-Fotoh, H.G., Abd El-Magid, A. A. and Monged Nadia, O. (2004). Some nutritional traits to increase broad bean yield and quality. Egypt. J. Appl. Sci.,19(9B): 736-750

6- Al-Juburi, H.j. ; Al-Mesry H. and Al-Banna M.F.(1992). Micronutrients and its effect on chlorophyll and carotene content of mandarin tree leaves cv. Balady. Com. In Sci. and Dev. Res. 37: $37-52$.

7- Amin, M.A.A.; Baza, M.S.M. and Al-Fendy, F.H. (1998). Effect of the number of sprays of some micronutrients on the growth, yield and mineral composition of broad bean plants. Ann.Agric. Sci. Moshtohor., 26:20072022. 
8- Bernier, C.C. Hanounik, S.B.; Hussein M.M. and Mohamed, H.A.( 1993). Field Manual of common Faba bean diseases in th Nile valley. International Center for Agricultural Research in the Dry Areas (ICARDA). Information Bulletin No.3.

9- Bozorgi, H.R.; Azarpour E. and Moradi, M.( 2011). The effects of bio, mineral nitrogen fertilization and foliar zinc spraying on yield and yield components of faba bean. World Apllied Sci.J., 13(6): 1409-1414.

10- Cook, R. J. and Baker, K.F.(1983). The nature and practice of biological control of plant pathogens. $1^{\text {st }}$ Edn., American Phytopathological Society, St. Paul, USA pp:539

11- El-Gamal Nadia, Abd-El-Kareem,G.F. Fotouh,Y.O. and El-Mougy, Nehal $S$. (2007). Induction of systemic resistance in potato plants against late and early blight diseases using chemical inducers under greenhouse and field conditions. Research J. Agrucultural and Biological Science, 3 (2) : 73-81.

12- El-Fouly, M.M.; Mobarak Z.M. and Salama,Z.A. (2010). Improving Tolerance of faba Bean during early growth stages to Salinity through Micronutrients foliar Spray. Academic press. Notulae Scientia Biologicae. 2(2): 98-102.

13- EL-Masri, M.F., Amberger,M.; Mohamed, M. ; El-Fouly M.M. and Rezk,A.L.( 2002). Zn increased flowering and pod setting in faba beans and its interaction with $\mathrm{Fe}$ in relation to their contents in different plant parts. Pakistan I. Biological Sci., 5(2): 143-145.

14- EL Sayed, Hameda E.A.; Amen EL-Shah.A.; El-Morsy, A.H. and Tolba M.H.( 2011). Effects of foliar spraying with microelements and different fertilizer sources on quality and yield of Pisum Sativum, L.plant

15- Foilett, R. H; Murphy, L.S and Danahue R. L.,(1981). Fertilizers and soil amendments. Prentice - Hall, Englewood cliffs. NJ. USA.

16- Grodzinsky, A.M. and Grodzinsky, D. M. (1973). Short reference in plant physiology. Naukova Domlka. Riev. R.U.R. pages, 433-34 (C.F. Thesis M.Sc. Ahmed. W.S., 1988. Univ. Alex.).

17- Hanounik,S.B. (1986) . Screening techniques for disease resistance in faba Bean. International Center for Agricultural Research in the Dry Areas (ICARDA), Aleppo, Syrig, PP : 59.

18- Hanounik, S.B. and Bisri,M., (1991). Status of diseases of faba bean in the Mediterranean region and their control. Ciheam options Mediterraneans, $10: 59-66$.

19- Harrison, J.G.,(1988). The biology of Botrytis spp. on vicia bean and chocolate spot disease-a review. Plant Pathol., 37: 168-201.

20- Hebblethwait, P.D. (ed.), 1983. The Faba Bean Butterworths. London. UK., pp:573.

21- Hesse, P.R., (1971). A text book of soil chemical analysis. John Murry (publishers) Ltd, London, U K.

22- Kalemba, D. and Kunicka, A.,(2003). Antibacterial and antifungal properties of essential oils. Curr. Med. Chem., $10: 813-829$.

23- Khaled, A.A.; Abd El-Moity S.M.H. and S.A.M. Omar,S.A.M,(1995). Chemical control of some faba bean disease with fungicides. Egypt $\mathrm{J}$. Agric. Res. 73:45-56. 
24- Mohamed, H.A.(1982). Major disease problems of faba bean in Egypt. In Faba bean improvement. Martinus Hawtin, G. and C. webb (eds.). Nijhoff Pub. PP. 213-225.

25- Naidu, A.S., (2000). Natural Food Antimicrobial Systems. CRC Press, Boca Raton, FL.

26- Omar, S.A.M., Salem D.E. and El-Gantiry, S.M.M,(1987). Methods for estimating micro-organisms population in faba bean phylloplane. Proceeding of the $2^{\text {nd }}$ National conference of pests and disease of vegetable and field Crops in Egypt, Ismailia, pp:886-889.

27- Rahhal, M.M.H.(1993) Effect of Microelements on some fungal diseases of broad bean. Alex. Sci. Exch., Vol. 14, No.(1) PP97-113.

28- Rahman, M.Z., Honda Y. Islam S.Z. and Arase, S, (2002). Effect of metabolic inhibitors on red light induced resistance of broad bean (Vicia faba L.) against Botrytis cinerea. J. Phytopathol., 150: 463-468.

29- Scheuerell, S.J. and Mahaffee, W. H, (2006). Variability Associated with suppression of Gray Mold (Botrytis cinerea) on Geranium by foliar applications of non-aerated and aerated compost teas. Plant Dis., 90 : 1201-1208.

30- Sinha, M.K. ; Raghbir, S. and Jeyarajan, R, (1970). Graphiola leaf spot on date-palm (Pheonix dactylifera). susceptibility of date varieties and effect on chlorophyll content. Plant Dis. Reptr.. 54: 617-619.

31- Yassen, A.; Abou El-Nour E.A.A. and Shedeed, S. (2010). Response of Wheat to foliar spary with urea and micronutrients, Journal of American Science $6(9): 14-22$.

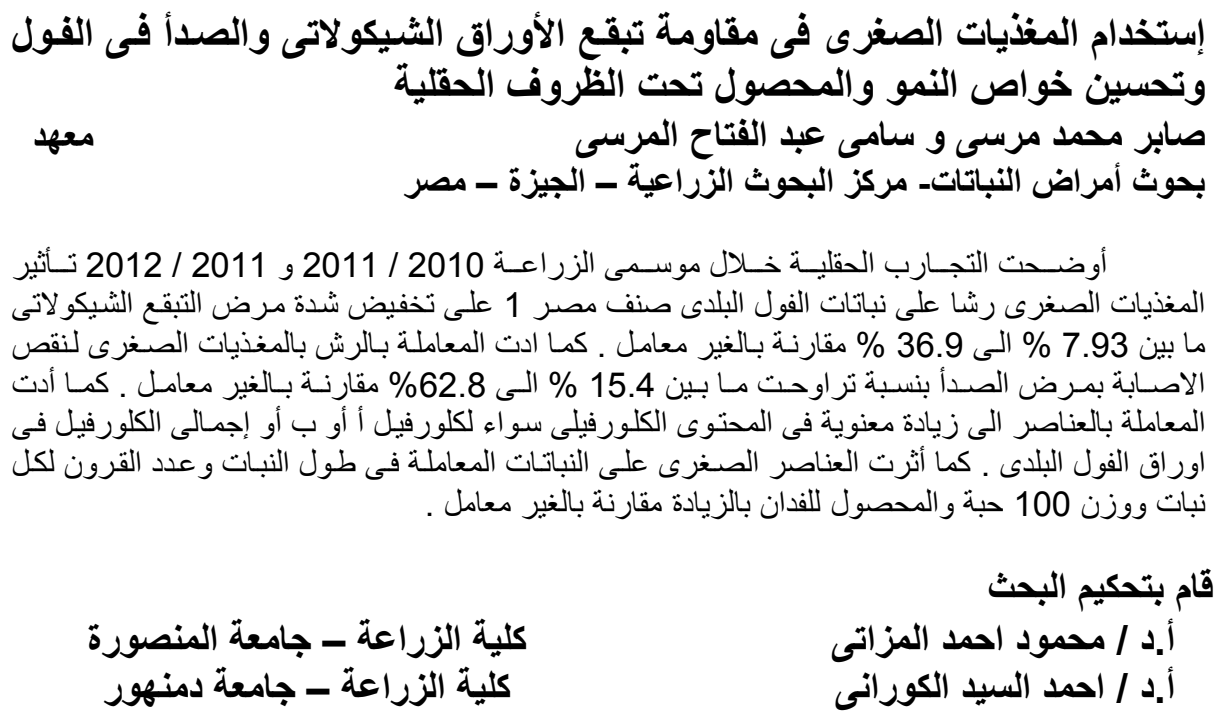


J. Plant Prot. and Path., Mansoura Univ., Vol. 4 (4), April, 2013 
Table (1) :Severity of chocolate leaf spot in faba bean plants, at three plant heights as affected by spraying with micronutrient under field conditions.

\begin{tabular}{|c|c|c|c|c|c|c|c|c|c|c|c|c|c|c|c|c|}
\hline \multirow{4}{*}{ Micronutrients } & \multicolumn{16}{|c|}{ (Chocolate leaf spot) } \\
\hline & \multicolumn{8}{|c|}{ First season 2010/ 2011} & \multicolumn{8}{|c|}{ Second season $2011 / 2012$} \\
\hline & \multicolumn{3}{|c|}{ Disease severity } & \multirow{2}{*}{ Mean } & \multicolumn{3}{|c|}{ Reduction \% } & \multirow{2}{*}{ Mean } & \multicolumn{3}{|c|}{ Disease severity } & \multirow{2}{*}{ Mean } & \multicolumn{3}{|c|}{ Reduction } & \multirow{2}{*}{ Mean } \\
\hline & $60 \mathrm{~cm}$ & $40 \mathrm{~cm}$ & $20 \mathrm{~cm}$ & & $60 \mathrm{~cm}$ & $40 \mathrm{~cm}$ & $20 \mathrm{~cm}$ & & $60 \mathrm{~cm}$ & $40 \mathrm{~cm}$ & $20 \mathrm{~cm}$ & & $60 \mathrm{~cm}$ & $40 \mathrm{~cm}$ & $20 \mathrm{~cm}$ & \\
\hline $\mathbf{F e}$ & 3.8 & 3.1 & 2.4 & 3.1 & 35.6 & 6.1 & 22.6 & 21.4 & 4.4 & 3.8 & 2.8 & 3.7 & 27.9 & 7.3 & 22.2 & 19.3 \\
\hline $\mathrm{Fe}+\mathrm{Zn}$ & 4.8 & 3.1 & 2.6 & 3.5 & 18.6 & 6.1 & 16.13 & 13.6 & 5.6 & 3.8 & 3.3 & 4.2 & 8.2 & 7.3 & 8.3 & 7.93 \\
\hline $\mathrm{Fe}+\mathrm{Mn}$ & 3.8 & 3.1 & 1.9 & 2.9 & 35.6 & 6.1 & 38.71 & 26.8 & 4.6 & 3.8 & 2.6 & 3.7 & 24.6 & 7.3 & 27.8 & 19.9 \\
\hline$F e+Z n+M n$ & 4.3 & 3.1 & 2.1 & 3.2 & 27.1 & 6.1 & 32.3 & 21.8 & 4.6 & 3.6 & 2.6 & 3.6 & 24.6 & 12.2 & 27.8 & 21.5 \\
\hline$Z n$ & 3.8 & 2.1 & 1.9 & 2.6 & 35.6 & 36.4 & 38.71 & 36.9 & 4.3 & 3.3 & 2.6 & 3.4 & 29.5 & 19.5 & 27.8 & 25.6 \\
\hline$Z n+M n$ & 4.7 & 2.4 & 1.9 & 3.0 & 20.3 & 27.3 & 38.1 & 28.6 & 4.8 & 3.1 & 2.6 & 3.5 & 21.3 & 24.4 & 27.8 & 24.5 \\
\hline Mn & 2.9 & 2.6 & 2.1 & 2.5 & 50.8 & 21.2 & 32.3 & 34.8 & 3.8 & 3.3 & 2.8 & 3.2 & 37.7 & 19.5 & 27.8 & 28.3 \\
\hline Diathean M 45 & 2.6 & 1.9 & 1.9 & 2.1 & 55.9 & 42.4 & 38.1 & 45.5 & 3.1 & 2.6 & 1.9 & 2.5 & 49.2 & 36.6 & 47.2 & 44.3 \\
\hline $\begin{array}{l}\text { Cheack(non - } \\
\text { treated }\end{array}$ & 5.9 & 3.3 & 3.1 & 4.1 & & & & & 6.1 & 4.1 & 3.6 & 4.6 & & & & \\
\hline L.S.D at 0.05 & 1.3 & n.s & 0.1 & & & & & & 1.4 & n.s & 0.7 & & & & & \\
\hline
\end{tabular}

L.S.D at 0.05

\begin{tabular}{l|l|l|l}
1.3 & n.s & 0.1
\end{tabular}

${ }^{*}$ Reduction compared to the untreatment( control).

Table (2) : Severity of rust disease on faba bean plants, at three plant heights, as affected by spraying with micronutrients under field condition.

\begin{tabular}{|c|c|c|c|c|c|c|c|c|c|c|c|c|c|c|c|c|}
\hline \multirow{3}{*}{$\begin{array}{l}\text { Application foliar spray } \\
\qquad 4 \mathrm{gm} / \mathrm{L}\end{array}$} & \multicolumn{7}{|c|}{ First season 2010 / 2011} & \multirow{3}{*}{ Mean } & \multicolumn{7}{|c|}{ Seconed season 2011 / 2012} & \multirow{3}{*}{ Mean } \\
\hline & \multicolumn{3}{|c|}{$\%$ Disease severity } & \multirow{2}{*}{ Mean } & \multicolumn{3}{|c|}{ Reduction \% } & & \multirow{2}{*}{\multicolumn{3}{|c|}{$\begin{array}{l}\text { \% Disease } \\
\text { severity }\end{array}$}} & \multirow{2}{*}{ Mean } & \multicolumn{3}{|c|}{ Reduction \% } & \\
\hline & $60 \mathrm{~cm}$ & $40 \mathrm{~cm}$ & $20 \mathrm{~cm}$ & & $60 \mathrm{~cm}$ & $40 \mathrm{~cm}$ & $20 \mathrm{~cm}$ & & & & & & & & & \\
\hline $\mathbf{F e}$ & 15.4 & 13.9 & 11.5 & 13.6 & 5.5 & 4.8 & 37.2 & 15.9 & 16.4 & 11.7 & 7.9 & 12.0 & 6.8 & 19.9 & 19.4 & 15.4 \\
\hline $\mathrm{Fe}+\mathrm{Zn}$ & 12.4 & 11.1 & 6.5 & 10.0 & 23.9 & 24.0 & 64.5 & 37.5 & 11.3 & 9.1 & 5.7 & 8.7 & 35.8 & 37.7 & 41.8 & 38.4 \\
\hline $\mathrm{Fe}+\mathrm{Mn}$ & 10.2 & 8.7 & 6.9 & 8.6 & 37.4 & 40.4 & 62.3 & 46.7 & 11.7 & 10.4 & 8.7 & 10.3 & 33.5 & 28.8 & 11.2 & 24.5 \\
\hline $\mathrm{Fe}+\mathrm{Zn}+\mathrm{Mn}$ & 9.8 & 4.3 & 4.0 & 6.03 & 39.9 & 70.5 & 78.1 & 62.8 & 8.3 & 9.1 & 6.3 & 7.9 & 52.8 & 37.7 & 35.7 & 42.1 \\
\hline Zn & 14.1 & 3.7 & 4.6 & 7.47 & 13.5 & 74.7 & 74.9 & 54.4 & 4.6 & 5.7 & 5.0 & 5.1 & 73.8 & 61.0 & 49.0 & 61.3 \\
\hline $\mathrm{Zn}+\mathrm{Mn}$ & 14.6 & 12.8 & 6.9 & 11.4 & 10.4 & 12.3 & 62.3 & 28.3 & 11.3 & 10.2 & 8.3 & 9.9 & 35.8 & 30.1 & \begin{tabular}{|c|}
15.3 \\
\end{tabular} & \begin{tabular}{|l|}
27.1 \\
\end{tabular} \\
\hline Mn & 11.3 & 9.3 & 6.1 & 8.9 & 30.7 & 36.3 & 66.7 & 44.6 & 9.8 & 8.3 & 4.6 & 7.6 & 44.3 & 43.2 & \begin{tabular}{|l|}
53.1 \\
\end{tabular} & 46.8 \\
\hline Dithane M - 45 & 5.0 & 4.6 & 2.8 & 4.13 & 69.3 & 68.5 & 84.7 & 74.2 & 3.9 & 5.0 & 3.7 & 4.2 & 77.8 & 65.8 & 62.2 & 68.6 \\
\hline Cheack (non - treated) & 16.3 & 14.6 & 18.3 & 16.4 & - & - & - & & 17.6 & 14.6 & 9.8 & 14.0 & - & - & \begin{tabular}{|l|}
- \\
\end{tabular} & \\
\hline L. S. D at $0.05 \%$ & 3.97 & 2.45 & 3.82 & & & & & & 3.84 & 5.4 & 4.37 & & & & & \\
\hline
\end{tabular}

Data are average of three replicates 